\title{
Caipira sweet orange + Rangpur lime: a somatic hybrid with potential for use as rootstock in the Brazilian citrus industry
}

\author{
Fernanda Januzzi Mendes-da-Glória ${ }^{1}$, Francisco de Assis Alves Mourão Filho ${ }^{2}$, Luis Eduardo Aranha \\ Camargo ${ }^{3}$ and Beatriz Madalena Januzzi Mendes ${ }^{4}$
}

\begin{abstract}
Protoplast culture following polyethylene glycol-induced fusion resulted in the regeneration of somatic hybrid plants between Caipira sweet orange (Citrus sinensis L. Osbeck) and Rangpur lime (C. limonia L. Osbeck). The plants were confirmed as somatic hybrids by leaf morphology, chromosome number and RAPD profile. All regenerated plants were tetraploid $(2 n=4 x=36)$, with intermediate leaf morphology and complementary RAPD banding profile of both parents. This combination may be useful as a rootstock for the citrus industry in Southeastern Brazil since this somatic hybrid could combine the drought tolerance and vigor of Rangpur lime with the blight tolerance of Caipira sweet orange.
\end{abstract}

\section{INTRODUCTION}

The State of São Paulo, in southeastern Brazil, accounts for one third of the world's orange production (Neves and Boteon, 1998). Almost $90 \%$ of the oranges produced in the state (estimated at 16.5 million metric tons in 1997/ 98) are converted into frozen concentrated juice, so that for every 10 cups of orange juice consumed in the world, eight come from the citrus groves of São Paulo State (Neves and Neves, 1996; Amaro and Maia, 1997). However, in the last few years important problems have threatened this orange production. Pests, diseases and climatic problems have limited expansion of the industry and have affected the quality of the harvest. Among the diseases, bacterial canker, citrus variegated chlorosis and blight are the most important (Fundecitrus, 1999).

A series of limitations, such as nucellar polyembryony (apomixis), heterozygosity, self and cross incompatibility and long juvenility, has made citrus breeding through conventional methods a difficult task (Soost and Cameron, 1975). However, recently developed technologies have helped breeders to overcome these difficulties. Among these techniques, somatic hybridization through protoplast fusion has proven to be a useful tool for developing inter-specific, and intra- and inter-generic allotetraploid somatic hybrids $(2 n=4 x=36)$. Somatic hybridization has been used in citrus breeding programs to combine complementary, elite scion varieties that can be used as pollen donors in interploid sexual hybridization to produce new seedless triploid fruit varieties (Grosser et al., 1992, 1998a; Mourão Filho et al., 1996); to produce allotetraploid hybrids among existing culti- vars with complementary characteristics for rootstock development (Grosser et al., 1994; Louzada et al., 1992; Grosser et al., 1998b) and to combine Citrus species with related, sexually incompatible genera that possess important traits for germplasm enhancement (Grosser et al., 1996).

The first example of somatic hybridization involving the genus Citrus was reported by Ohgawara et al. (1985) who obtained an intergeneric allotetraploid hybrid from the fusion of embryogenic callus-derived protoplasts of Trovita sweet orange (C. sinensis) and mesophyll protoplasts of Poncirus trifoliata, a sexually compatible Citrus-related species. Since then, several citrus breeding programs involving somatic hybridization have been started in countries such as the United States (Grosser and Gmitter Jr., 1990), France (Ollitrault and Luro, 1995), Japan (Kobayashi and Ohgawara, 1988; Miranda et al., 1997) and Israel (Vardi et al., 1987). More than 150 Citrus somatic hybrids have been reported during the last 15 years (Ohgawara et al., 1994; Grosser et al., 1995) with some hybrids displaying interesting agronomic traits such as ovule fertility (Kobayashi et al., 1991) and reduced tree size when used as rootstocks (Grosser et al., 1995).

A routine procedure for somatic hybridization of Brazilian citrus varieties has been described by Mendes-daGlória et al. (1999). We report the production of somatic hybrids between Rangpur lime and Caipira sweet orange. This combination is expected to combine good horticultural traits from Rangpur lime, such as drought and citrus tristeza virus tolerance and good vigor, with blight tolerance from Caipira.

${ }^{1}$ Curso de Pós-Graduação em Fitotecnia, Departamentos de

${ }^{1,2}$ Produção Vegetal, and ${ }^{3}$ Entomologia, Fitopatologia e Zoologia Agrícola, ESALQ/USP, Piracicaba, SP, Brasil. ${ }^{4}$ Laboratório de Biotecnologia Vegetal, CENA/USP, Caixa Postal 96, 13400-970 Piracicaba, SP, Brasil. Send correspondence to B.M.J.M. 


\section{MATERIAL AND METHODS}

\section{Plant material}

An embryogenic cell suspension culture derived from Caipira sweet orange (Citrus sinensis L. Osbeck) nucellar callus was maintained in liquid EME medium (Grosser and Gmitter Jr., 1990) at $100 \mathrm{rpm}$, in the dark, at $27^{\circ} \mathrm{C}$, on a 2-week culture cycle. Rangpur lime plants (Citrus limonia L. Osbeck) derived from nucellar seedlings were grown in RMAN medium (Grosser and Gmitter Jr., $1990)$ at $27^{\circ} \mathrm{C}$ under $16 \mathrm{~h}$ of light.

\section{Protoplast isolation, fusion and culture}

Protoplasts were isolated from cell suspension cultures and leaves and were chemically fused as described by Mendes-da-Glória et al. (1999). Cells from suspension cultures were used for protoplast isolation seven days after subculture. After fusion, the protoplasts were cultured in 0.7 M BH3, 0.7 M EME or BH3:EME medium (1:1 v/v, Grosser and Gmitter Jr., 1990), in 58 x 15-mm plastic dishes sealed with parafilm and incubated in the dark at $27^{\circ} \mathrm{C}$. After 3-5-week incubation, cultures were supplemented with medium for osmotic reduction (Mendes-da-Glória et al., 1999). For the development of somatic embryos, calli were transferred to EME medium containing $25 \mathrm{~g}$ of sucrose/l. Well-formed embryos were germinated in EME medium with gibberellic acid (1 mg/ 1). Regenerated plants with 4-5 leaves were transferred to a greenhouse for acclimatization.

\section{Analyses of regenerated plants}

Confirmation of the hybrid nature of the regenerated plants was based on morphology (leaf thickness and petiole shape), chromosome number and RAPD analyses.

For the determination of chromosome number, root tips from regenerated plants were excised 3-4 $\mathrm{h}$ after the onset of light and placed in $0.2 \mathrm{mM}$ hydroxyquinoline for $3 \mathrm{~h}$ at room temperature. After this incubation, the root tips were rinsed in distilled water and fixed in a solution of $100 \%$ ethanol:acetic acid $(3: 1, \mathrm{v} / \mathrm{v})$ for $18 \mathrm{~h}$. Root tips were then rinsed in distilled water, hydrolyzed at $60^{\circ} \mathrm{C}$ in $1 \mathrm{~N} \mathrm{HCl}$ for $8 \mathrm{~min}$, rinsed again in distilled water for 5 min and stained in Schiff solution (leuco basic fucsin) for $45 \mathrm{~min}$ in the dark (Vieira, 1988). After staining, the root tips were rinsed in distilled water and spread on a glass slide containing a drop of $45 \%$ acetic acid solution. Cell preparations were mounted in Entellan and scanned for metaphase cells at 200X magnification. Chromosomes were counted at $1250 \mathrm{X}$ magnification.

Leaves from the parental plants and from the putative somatic hybrids were collected for total DNA extraction, according to Hoisington et al. (1994). One or two leaves (about $200 \mathrm{mg}$ ) were ground in liquid nitrogen for approximately $1 \mathrm{~min}$ and an aliquot $(500 \mu \mathrm{l})$ of extration buffer $(100 \mathrm{mM}$ Tris, $\mathrm{pH} 7.5,700 \mathrm{mM} \mathrm{NaCl}, 50 \mathrm{mM}$ EDTA, pH 8.0, 1\% CTAB (hexadecyltrimethylammonium bromide), $140 \mathrm{mM} \beta$-mercaptoethanol) was added to the samples, which were then incubated at $65^{\circ} \mathrm{C}$ in a water bath for $60 \mathrm{~min}$ prior to extraction with an equal volume of a 24:1 chloroform:isoamyl alcohol (CIA; 24:1,v/v) followed by centrifugation for $10 \mathrm{~min}$ at $16000 \mathrm{~g}$. The supernatant was transferred to another tube and extracted with $400 \mu \mathrm{l}$ of Tris-equilibrated phenol. The tubes were centrifuged again for $10 \mathrm{~min}$ at 16,000 $\mathrm{g}$ and the supernatant transferred to a clean tube for DNA precipitation with $400 \mu \mathrm{l}$ of $100 \%$ ethanol. The samples were placed in a freezer $\left(-20^{\circ} \mathrm{C}\right)$ for $10 \mathrm{~min}$ and then centrifuged as described above. The pellets were rinsed in $75 \%$ ethanol for $10 \mathrm{~min}$, air-dried, resuspended in $480 \mu \mathrm{l}$ of Tris-EDTA (TE) buffer, $\mathrm{pH} 8.0$, and re-precipitated with $130 \mu \mathrm{l}$ of 5 $\mathrm{M} \mathrm{NaCl}$ and $1 \mathrm{ml} 100 \%$ ethanol as described above. After a double rinse, the DNA was resuspended in $50 \mu \mathrm{l}$ of TE buffer, $\mathrm{pH}$ 8.0.

Total genomic DNA fragments from both parents were amplified with 21 10-mer primers (Operon Technologies) by the polymerase chain reaction (PCR). Reactions were conducted with a PTC-100 thermal controller (MJ Research) using an initial denaturation step of $93^{\circ} \mathrm{C}$ for 2 min followed by 43 cycles at $92^{\circ} \mathrm{C}$ for $1 \mathrm{~min}, 37^{\circ} \mathrm{C}$ for $1 \mathrm{~min}$, and $72^{\circ} \mathrm{C}$ for $2 \mathrm{~min}$. A final elongation step was carried out at $72^{\circ} \mathrm{C}$ for $5 \mathrm{~min}$. Each $20 \mu \mathrm{l}$ of reaction mixture contained $100 \mathrm{mM}$ Tris- $\mathrm{HCl}, \mathrm{pH} 9.0,500 \mathrm{mM} \mathrm{KCl}$, $2.0 \mu \mathrm{l} 10 \mathrm{X}$ taq polymerase buffer, $2.5 \mathrm{mM} \mathrm{MgCl}, 100$ $\mu \mathrm{M}$ of each dNTP, $30 \mathrm{ng}$ of primer, $1 \mathrm{U}$ of taq DNA polymerase and $30 \mathrm{ng}$ of total genomic DNA. The amplification products were separated by electrophoresis $(45 \mathrm{~V}$ for $4.5 \mathrm{~h}$ at room temperature) in ethidium bromide-stained $1.5 \%$ agarose gels $(0.5 \mu \mathrm{g} \mathrm{EtBr} / \mathrm{ml}$ of gel) with $0.5 \mathrm{X} 45$ $\mathrm{mM}$ Tris, $45 \mathrm{mM}$ boric acid, $1 \mathrm{mM}$ EDTA (TBE) buffer. The gels were photographed under UV light.

\section{RESULTS AND DISCUSSION}

Protoplast fusion allows the production of interspecific and intergeneric allotetraploid somatic hybrids and generates new combinations unobtainable by conventional breeding methods (Ohgawara et al., 1994; Grosser et al., 1996). This should be useful for citrus breeding programs.

Initial callus culture on regular EME (Grosser and Gmitter Jr., 1990) does not induce somatic embryogenesis. The number of embryos induced on this medium is very low in spite of several reports showing that sucrose is the carbon source for citrus somatic embryogenesis (Kobayashi and Ohgawara, 1988; Grosser and Gmitter Jr., 1990; Ohgawara et al., 1994; Grosser et al., 1996; Mourão Filho et al., 1996). We have observed, in fusion experiments involving other parental combinations, that many embryos developed in the same EME basal medium 

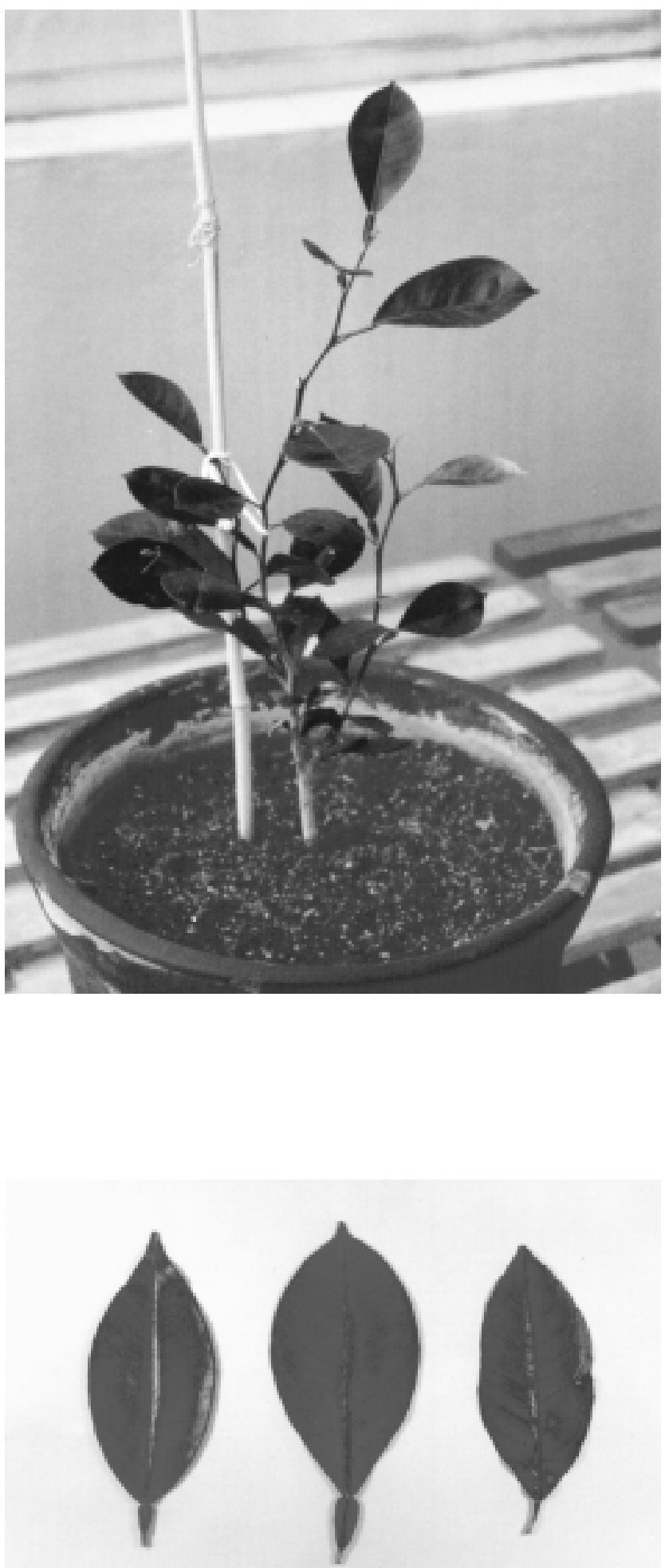

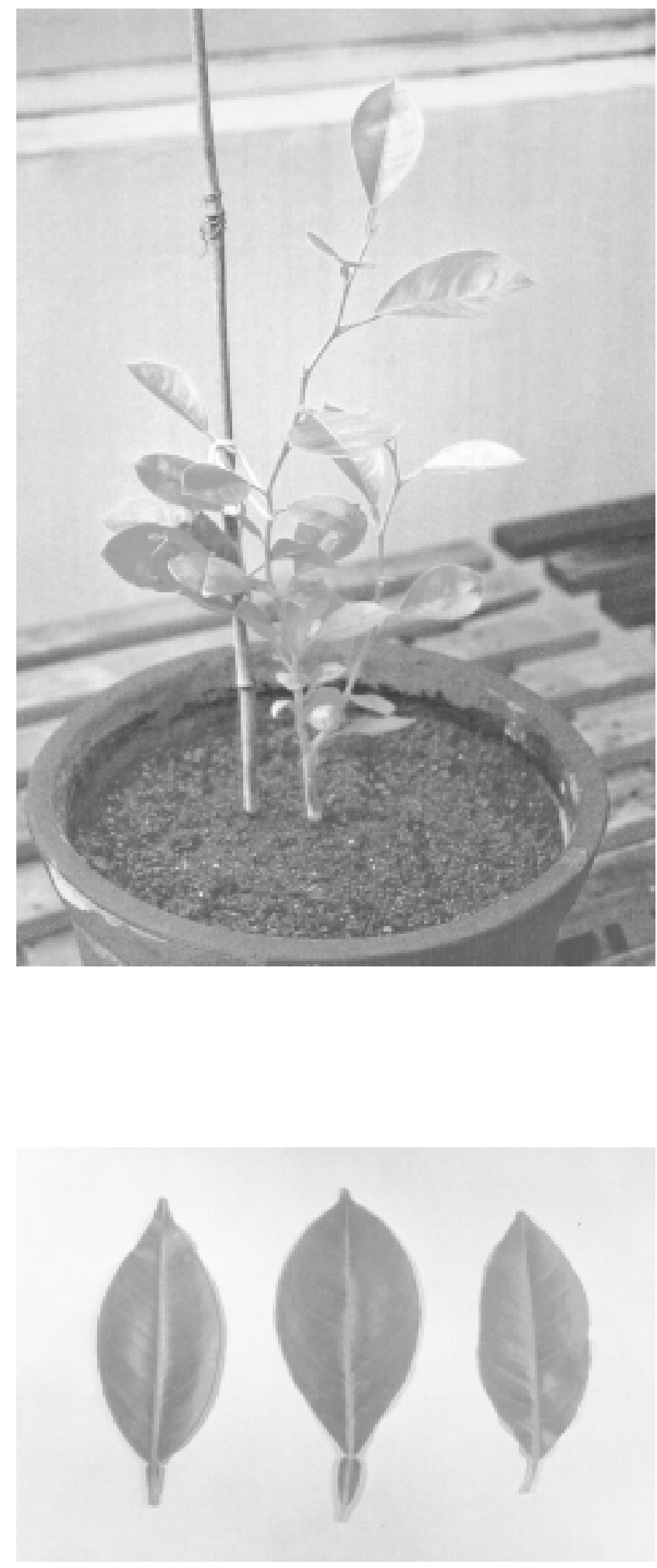

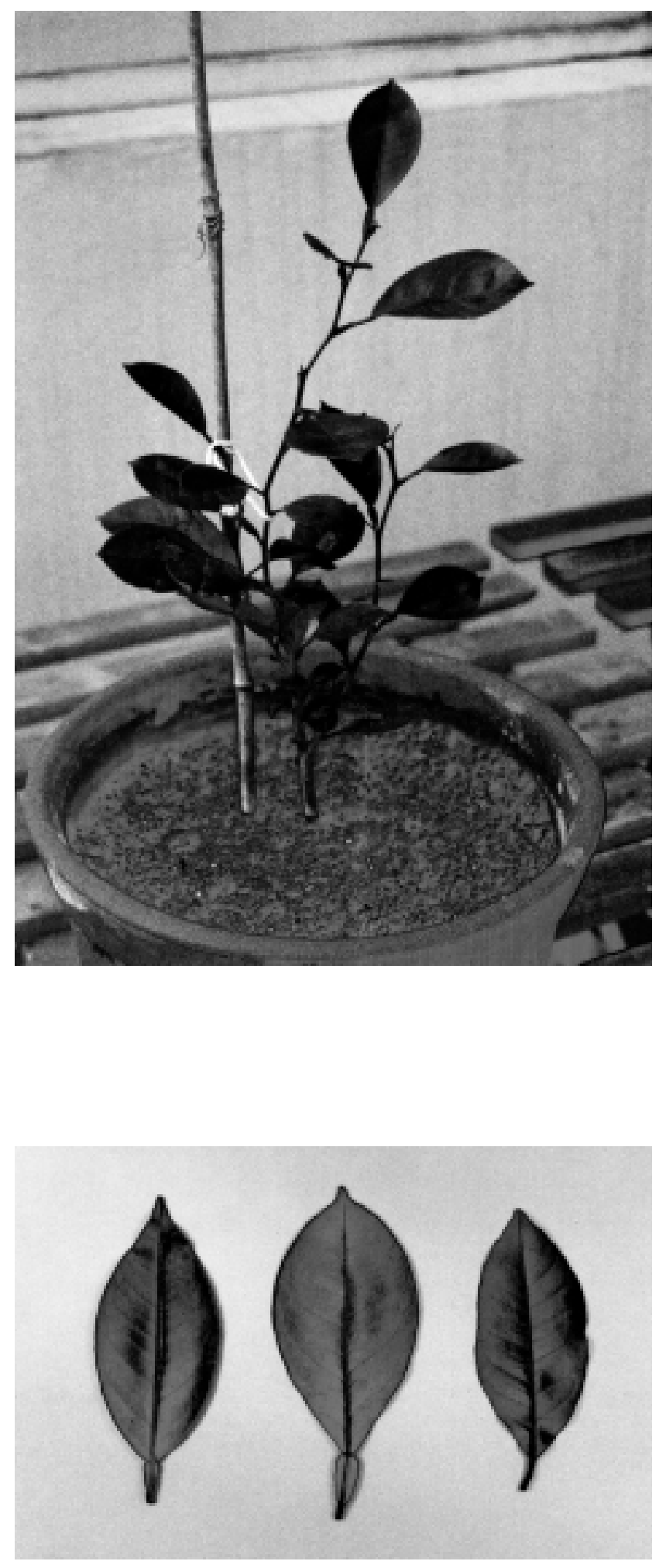
when sucrose was substituted by maltose ( $25 \mathrm{~g} / \mathrm{l})$ (Perez et al., 1998). Several studies have demonstrated the positive influence of other carbon sources, including lactose (Ling et al., 1990; Kunitake et al., 1991), galactose (Kochba et al., 1978, 1982) and glycerol (Vu et al., 1993), on the somatic embryogenesis of citrus plants.

Recovered somatic embryos have a shape different from that of typical somatic embryos. Secondary embryogenesis is also observed (Ohgawara et al., 1985; Louzada et al., 1992), with pluricotyledonary embryos, multiple shoot meristems, fused embryos and fasciation (Jumin and Nito, 1996), but this does not interfere with germination and plant recovery. Embryo development is better in EME medium with $25 \mathrm{~g}$ of sucrose/ $/ \mathrm{than}$ with $50 \mathrm{~g}$ of sucrose/ 1 (Grosser and Gmitter Jr., 1990). Lower sucrose levels influenced embryo development and suppressed calli growth. More than 100 embryos were regenerated after callus culture. Most of these embryos were recovered from protoplast culture on $0.7 \mathrm{M} \mathrm{BH} 3$ or $\mathrm{BH} 3$ :EME medium $(1: 1 \mathrm{v} / \mathrm{v})$. These embryos continued to be subcultured on solid EME for development. Embryo culture on media with a higher concentration of malt extract (1500 mg/l) (Grosser and Gmitter Jr., 1990) was not beneficial for embryo development in this case. Some small embryos transferred to this media showed callus formation and no development. Embryo germination occurred in EME medium containing $1 \mathrm{mg}$ of GA3/l. A large number of these embryos germinated (about $75 \%$ germination) and produced morphologically normal plants, which were transferred to a greenhouse (Figure 1). Twenty-five plants were recovered and well acclimated in the greenhouse. Protoplast fusion to plant regeneration lasted about 18 months.

The leaf morphology of all the recovered plants was intermediate to that of the parents. In addition, leaves from somatic hybrid plants had a bigger petiole wing and thicker leaf blade compared to both parental types (Figure 2), a finding typical of somatic hybrids and polyploids (Miranda et al., 1997). Chromosome counts confirmed the tetraploid nature of the regenerated plants (Figure 3).

Somatic hybridization can be further confirmed by the analysis of molecular markers such as isozymes (Grosser et al., 1988; Ling and Iwamassa, 1994), rDNA restriction endonuclease digestion patterns (Ohgawara et al., 1985; Miranda et al., 1997), and RAPD-PCR (Grosser et al., 1996; Mourão Filho et al., 1996). RAPD analysis confirmed the somatic hybridization and revealed complementary banding paterns in the somatic hybrid Caipira sweet orange + Rangpur lime, indicating the presence of DNA from each parent in the corresponding hybrid (Figure 4). Six out of 21 primers showed polymorphic bands. DNA fragments amplified with primers OPAA3, OPAB5 and OPAB7 indicated the presence of Caipira sweet orange DNA, whereas DNA amplified using the primers OPAA7 and OPAB 1 confirmed the presence of Rangpur lime DNA in the somatic hybrids. DNA

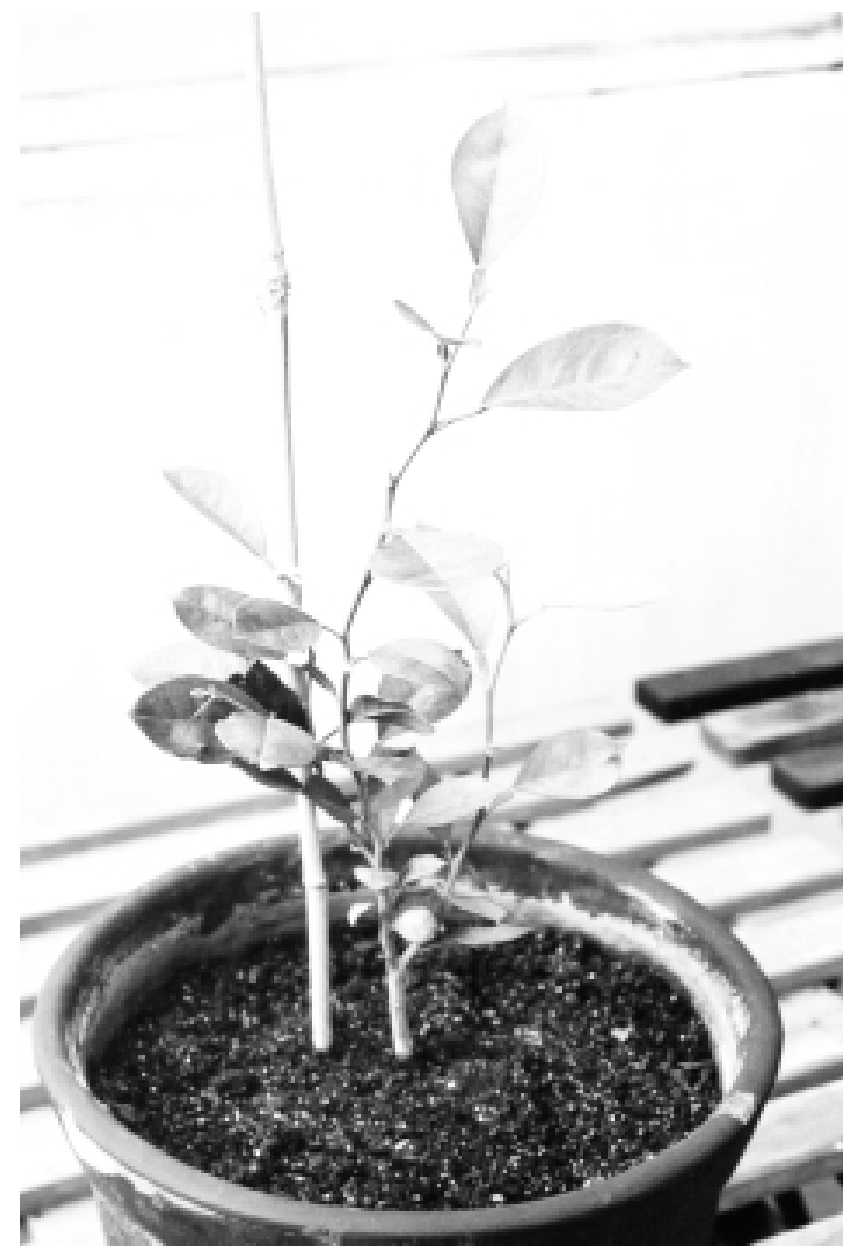

Figure 1 - Regenerated somatic hybrid plant of Caipira sweet orange + Rangpur lime.
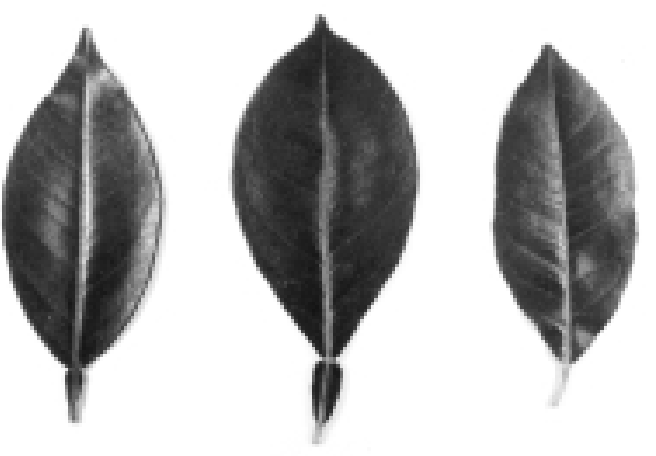

Figure 2 - Leaf morphology of Citrus sinensis (left), somatic hybrid (center), and C. limonia (right). 


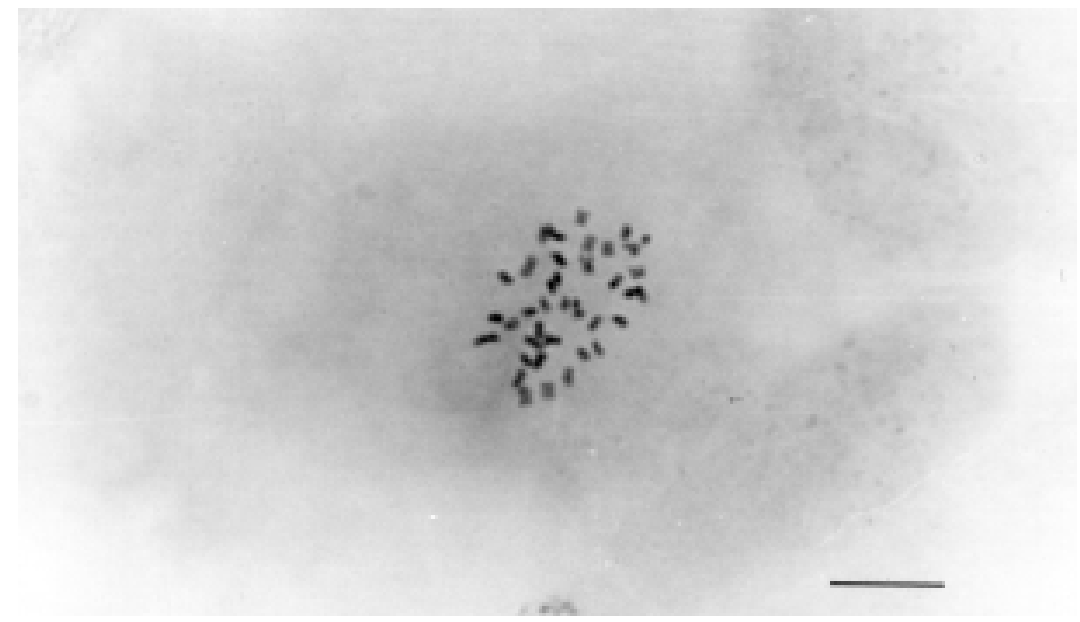

Figure 3 - Mitotic metaphase of a somatic hybrid plant showing $2 n=4 x=36(B a r=1 \mu \mathrm{m})$.

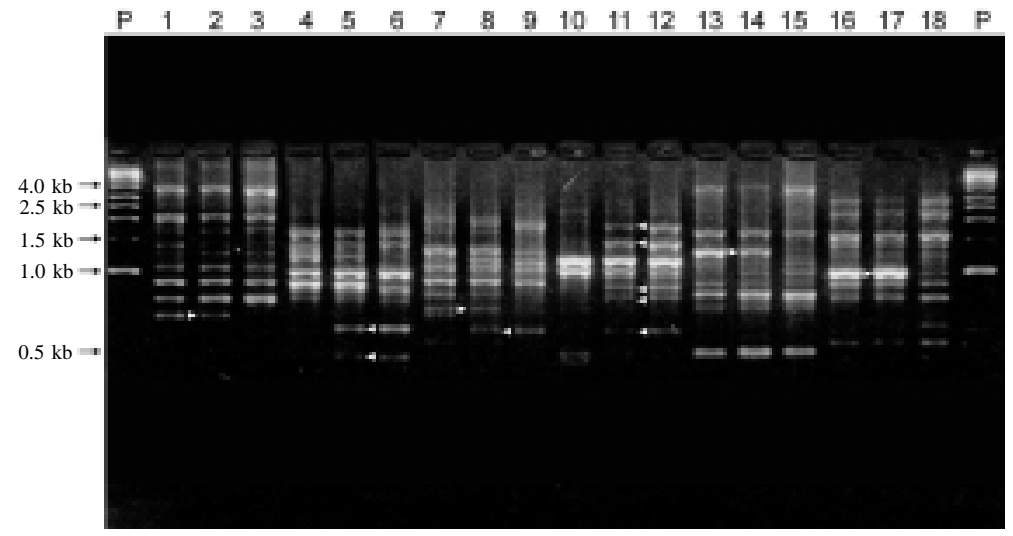

Figure 4 - RAPD fragments of the parental lines Caipira (lanes 1,4, 7, 10,13 and 16) and Rangpur lime (lanes 3, 6, 9, 12,15 and 18) and their somatic hybrid (lanes 2, 5, 8, 11, 14 and 17) amplified with primers OPAA3 (lanes 1-3), OPAA7 (lanes 4-6), OPAA18 (lanes 7-9), OPAB5 (lanes 10-12) and OPAB7 (lanes 16-18). P = 1.0 kb ladder.

amplified with the primer OPAA18 revealed the contribution of DNA from both parents.

Somatic hybrid regeneration confirmed the efficiency of selection medium with a high content of sucrose when sweet orange is a parent (Ohgawara et al., 1985; Motomura et al., 1995) as only fused protoplasts formed embryos. It also demonstrated the efficiency of the protocol adopted for Brazilian citrus cultivars (Mendes-daGlória et al., 1999). The regenerated somatic hybrids are currently maintained under greenhouse conditions and show adequate vigor. This hybrid may be useful as a rootstock since it should combine the drought tolerance and vigor of Rangpur lime with the blight tolerance of Caipira sweet orange, though it may have some susceptibility to Phytophthora. Another combination of sweet orange + Rangpur lime was previously described by Louzada et al. (1992) with the somatic hybridization between 'Hamlin' sweet orange and Rangpur lime.

\section{ACKNOWLEDGMENTS}

This research was supported by Fundação de Amparo à Pesquisa do Estado de São Paulo (FAPESP). The authors thank Dr. M.L.C. Vieira for help in the chromosome counting. F.J. Mendes-da-Glória was the recipient of a FAPESP fellowship. F.A.A. Mourão Filho, L.E.A. Camargo and B.M.J. Mendes were recipients of CNPq fellowships. Publication supported by FAPESP.

\section{RESUMO}

Híbridos somáticos de laranja doce (Citrus sinensis L. Osbeck) e limão Cravo (C. limonia L. Osbeck) foram regenerados após a fusão (polietileno glicol) e cultura de protoplastos. Os híbridos somáticos foram confirmados pela análise da morfologia das folhas, determinação do número de cromossomos e marcadores moleculares (RAPD). Todas as plantas analisadas revelaram-se tetraplóides $(2 \mathrm{n}=4 \mathrm{x}=36)$, possuíam folhas de morfologia intermediária e uma combinação do padrão de bandas 
de RAPD de ambos os parentais. Esta combinação pode se tornar útil como porta-enxerto para a Região Sudeste da indústria citrícola brasileira. Este híbrido somático potencialmente combinará as características de tolerância à seca e o vigor do limão Cravo com a tolerância ao declínio da laranja Caipira.

\section{REFERENCES}

Amaro, A.A. and Maia, M.L. (1997). Produção e comércio de laranja e de suco no Brasil. Inf. Econ. 27: 11-23.

Fundecitrus (1999). http://www.fundecitrus.com.br/ (10 de dezembro de 1999).

Grosser, J.W. and Gmitter Jr., F.G. (1990). Protoplast fusion and citrus improvement. Plant Breed. Rev. 8: 339-374.

Grosser, J.W., Gmitter Jr., F.G. and Chandler, J.L. (1988). Intergeneric somatic hybrid of Citrus sinensis cv. Hamlin and Poncirus trifoliata cv. Flying Dragon. Plant Cell Rep. 7: 5-8.

Grosser, J.W., Gmitter Jr., F.G., Sesto, F., Deng, X.X. and Chandler, J.L. (1992). Six new somatic citrus hybrids and their potential for cultivar improvement. J. Am. Soc. Hort. Sci. 117: 169-173.

Grosser, J.W., Louzada, E.S., Gmitter Jr., F.G. and Chandler, J.L. (1994). Somatic hybridization of complementary citrus rootstocks: five new hybrids. HortScience 29: 812-813.

Grosser, J.W., Gmitter Jr., F.G., Castle, W.S. and Chandler, J.L. (1995) Production and evaluation of citrus somatic hybrid rootstocks: progress report. Proc. Fl. State Hortic. Soc. 108: 140-143.

Grosser, J.W., Mourão Filho, F.A.A., Gmitter Jr., F.G., Louzada, E.S., Jiang, J., Baergen, K., Quiros, A., Cabasson, C., Schell, J.L. and Chandler, J.L. (1996). Allotetraploid hybrids between Citrus and seven related genera produced by somatic hybridization. Theor. Appl. Genet. 92: 577582.

Grosser, J.W., Jiang, J., Mourão Filho, F.A.A., Louzada, E.S., Baergen, K., Chandler, J.L. and Gmitter Jr., F.G. (1998a). Somatic hybridization, an integral component of Citrus cultivar improvement: I. Scion improvement. HortScience 33: 1057-1059.

Grosser, J.W., Jiang, J., Louzada, E.S., Chandler, J.L. and Gmitter Jr., F.G. (1998b). Somatic hybridization, an integral component of Citrus cultiva improvement: II. Rootstock improvement. HortScience 33: 1060-1061.

Hoisington, D., Khairallah, M. and González-de-León, D. (1994). Laboratory Protocols: CIMMYT Applied Molecular Genetics Laboratory. CIMMYT, Mexico.

Jumin, H.B. and Nito, N. (1996). Plant regeneration via somatic embryogenesis from protoplasts of six plant species related to Citrus. Plant Cell Rep. 15: 332-336.

Kobayashi, S. and Ohgawara, T. (1988). Production of somatic hybrid plants through protoplast fusion of citrus. Jpn. Agric. Res. Q. 22: 181-188.

Kobayashi, S., Oiyama, I., Yoshinaga, K., Ohgawara, T. and Ishii, S. (1991) Fertility in an intergeneric somatic hybrid plant of Rutaceae. HortScience 26: 207.

Kochba, J., Spiegel-Roy, P., Saad, S. and Neumann, H. (1978). Stimulation of embryogenesis in Citrus tissue culture by galactose. Naturwissenschaften 65: 261-262.

Kochba, J., Spiegel-Roy, P., Neumann, H. and Saad, S. (1982). Effect of carbohydrates on somatic embryogenesis in subcultured nucellar callus of Citrus cultivars. Z. Pflanzenphysiol. Bd. 105: 359-368.

Kunitake, H., Kagami, H. and Mii, M. (1991). Somatic embryogenesis and plant regeneration from protoplasts of Satsuma mandarin (Citrus unshiu marc.). Sci. Hortic. 47: 27-33.

Ling, J.-T. and Iwamassa, M. (1994). Somatic hybridization between Citrus reticulata and Citropsis gabunensis through electrofusion. Plant Cell Rep. 13: 493-497.

Ling, J.-T., Nito, N., Iwamassa, M. and Kunitake, H. (1990). Plant regeneration from protoplasts isolated from embryogenic callus of Satsuma. HortScience 25: 970-972.

Louzada, E.S., Grosser, J.W., Gmitter Jr., F.G., Nielsen, B., Chandler, J.L., Deng, X.X. and Tusa, N. (1992). Eight new somatic hybrid citrus rootstocks with potential for improved disease resistance. HortScience 27: 1033-1036.

Mendes-da-Glória, F.J., Mourão Filho, F.A.A. and Mendes, B.M.J. (2000) Plant regeneration from protoplast of Brazilian citrus cultivars. Pesqui. Agropecu. Bras. 35: 727-732.

Miranda, M., Motomura, T., Ikeda, F., Ohgawara, T., Saito, W., Endo, T., Omura, M. and Mouriguchi, T. (1997). Somatic hybrids obtained by fusion between Poncirus trifoliata (2x) and Fortunella hindsii $(4 \mathrm{x})$ protoplasts. Plant Cell Rep. 16: 401-405.

Motomura, T., Hidaka, T., Mouriguchi, T., Akihama, T. and Omura, M. (1995). Intergeneric somatic hybrids between Citrus and Atalantia or Severinia by electrofusion, and recombination of mitochondrial genomes. Breed. Sci. 45: 309-314

Mourão Filho, F.A.A., Grosser, J.W. and Gmitter Jr., F.G. (1996). New tetraploid breeding parents for triploid seedless citrus development. Fruit Var. J. 50: 76-80.

Neves, E.M. and Boteon, M. (1998). Impactos alocativos e distributivos na citricultura. Preços Agríc. 136: 3-6.

Neves, E.M. and Neves, M.F. (1996). Suco concentrado de laranja: uma comodity "sui generis". Preços Agríc. 119: 8-10.

Ohgawara, T., Kobayashi, S., Ohgawara, E., Uchimiya, H. and Ishii, S. (1985). Somatic hybrid plants obtained by protoplast fusion between Citrus sinensis and Poncirus trifloliata. Theor. Appl. Genet. 71: 1-4.

Ohgawara, T., Uchimiya, H., Ishii, S. and Kobayashi, S. (1994). Somatic hybridization between Citrus sinensis and Poncirus trifoliata. In: Somatic Hybridization in Crop Improvement. I (Bajaj, Y.P.S., ed.). SpringerVerlag, Berlin, pp. 439-454.

Ollitrault, P. and Luro, F. (1995). Amélioration des agrumes et biotechnologie. Fruits 50: 267-279.

Perez, R.M., Galiana, A.M., Navarro, L. and Duran-Vila, N. (1998). Embryogenesis in vitro of several Citrus species and cultivars. J. Hortic. Sci. Biotechnol. 73: 796-802.

Soost, R.K. and Cameron, J.W. (1975). Citrus. In: Advances in Fruit Breeding (Janick, J. and Moore, J.N., eds.). Purdue University Press, West Lafayette, pp. 229-241.

Vardi, A., Breiman, A. and Galun, E. (1987). Citrus cybrids: production by donor-recipient protoplast-fusion and verification by mitochondrialDNA restriction profiles. Theor. Appl. Genet. 75: 51-58.

Vieira, M.L.C. (1988). Estudo citotaxonômico de espécies brasileiras do gênero Stylosanthes Sw. Doctoral thesis, ESALQ-USP, Piracicaba, SP.

Vu, J.C.V., Niedz, R.P. and Yelenosky, G. (1993). Glycerol stimulation of chlorophyll synthesis, embryogenesis, and carboxylation and sucrose metabolism enzymes in nucellar callus of "Hamlin" sweet orange. Plant Cell Tiss. Org. Cult. 33: 75-80.

(Received June 18, 1999) 
